\title{
Soil characteristics and plant distribution in saline wetlands of Oued Righ, northeastern Algeria
}

\author{
Naïma KOULL ${ }^{1,2 *}$, Abdelmadjid CHEHMA ${ }^{2}$ \\ ${ }^{1}$ Division of Desertification Surveillance, Scientific and Technical Research Center of Arid Areas, Touggourt 30200, Algeria; \\ ${ }^{2}$ Saharan Bio-resources Laboratory, Safeguarding and Valorization, Kasdi Merbah University of Ouargla, Ouargla 30000 , \\ Algeria
}

\begin{abstract}
Saline wetlands are rare ecosystems in Saharan areas, which are important for conservation of many endemic and rare plant species. In this study, we investigated five saline wetland sites of the Oued Righ region, located in the northeastern Algeria, to determine the environmental factors controlling the composition and distribution of plant communities. We established a total of 20 transects to measure the vegetation parameters (density and cover) and soil characteristics (electrical conductivity, moisture, $\mathrm{pH}, \mathrm{CaSO}_{4}, \mathrm{CaCO}_{3}$, organic matter, $\mathrm{Na}^{+}, \mathrm{K}^{+}$, $\mathrm{Mg}^{2+}, \mathrm{Ca}^{2+}, \mathrm{SO}_{4}{ }^{2-}, \mathrm{Cl}^{-}, \mathrm{NO}_{3}{ }^{-}$and $\left.\mathrm{HCO}_{3}{ }^{-}\right)$. A total of 17 plant species belonging to seven families were identified. The natural vegetation was composed of halophytic and hydro-halophytic plant communities, presented specially by the species of Amaranthaceae family. Soils in the studied wetlands were moist, gypsiferous, alkaline, salty to very salty with dominance of chloride and calcium. Results of the Canonical Correspondence Analysis (CCA) showed that community structure and species distribution patterns of vegetation were mainly dependent on soil characteristics, mainly being soil salinity $\left(\mathrm{CaSO}_{4}, \mathrm{~K}^{+}, \mathrm{Ca}^{2+}\right.$ and $\left.\mathrm{Cl}^{-}\right)$and moisture. The distribution of plant species was found to follow a specific zonal pattern. Halocnemum strobilaceum was observed to grow in highly salt-affected soils, thus being the more salt-tolerant species. Phragmites communis plants were widely distributed in the study area with a high density at the edges of accumulated water body. Juncus maritimus, Tamarix gallica and Salicornia fructicosa grew in soils that are partially or completely flooded in winter. Suaeda fructicosa, Traganum nudatum, Arthrocnemum glaucum, Aeluropus littoralis, Cressa cretica and Cynodon dactylon were distributed in salty and moist soils away from the open water body. Plants of Zygophyllum album, Limonastrirum guyonianum, Cornulaca monacantha, Cistanche tinctoria, Mollugo nudicaulis and Sonchus maritimus were found in soils with less salty and moisture. They constituted the outermost belt of vegetation in the studied wetlands. This study will provide a reference on introducing the salt-tolerant plant species as a fodder resource in saline habitats and regenerating the degraded saline wetlands.
\end{abstract}

Keywords: saline wetlands; soil properties; vegetation composition; Sahara; Algeria

Citation: Naïma KOULL, Abdelmadjid CHEHMA. 2016. Soil characteristics and plant distribution in saline wetlands of Oued Righ, northeastern Algeria. Journal of Arid Land, 8(6): 948-959. doi: 10.1007/s40333-016-0060-5

The region of Oued Righ, located in the low basin of the northeastern Algeria (a part of Sahara Desert), occupies an area of about $6 \times 10^{5} \mathrm{~km}^{2}$. Despite the arid climate, there are several wetlands as well. These Saharan wetlands are important ecosystems both in space and time, compared to their dry environments (Heker and Tomàs Vives, 1995). The region of Oued Righ is subject to

*Corresponding author: Naïma KOULL (E-mail: kllnaima@gmail.com)
Received 2015-12-15; revised 2016-05-08; accepted 2016-06-08
(C) Xinjiang Institute of Ecology and Geography, Chinese Academy of Sciences, Science Press and Springer-Verlag Berlin Heidelberg 2016 
suffering from harsh climate change and desertification (Le Houérou, 2001). However, the presence of water plays an important role for the survival of the majority of desert life forms (Roshier et al., 2001; García et al., 2010). The saline wetlands are important for conservation of many endemic and rare plant species and migration of water birds. In the saline wetland ecosystems, spontaneous halophytes vegetations are ecologically very interesting in addition to their roles as pastures. The saline wetlands of the Oued Righ region display fluctuations in soil moisture and salinity throughout the year. Although soil moisture and salinity are important factors determining the distribution of plant species (Hoveizeh, 1997), we cannot exclude the importance of biological factors on plant species distribution (Cooper, 1982; Snow and Vince, 1984), such as inter-specific competition.

The effect of abiotic factors can be understood in the borders of saline wetland when or where soil properties change gradually (Clarke and Hannon, 1967, 1970; Pennings and Callaway, 1992; Ungar, 1998). However, only a few studies have examined the effect of environmental factors on the distribution of vegetation in the northeastern Algeria, especially the Oued Righ region (Chenchouni, 2012; Youcef et al., 2012; Koull and Chehma, 2015). Moreover, floral biodiversity in this area remains poorly understood. As saline wetlands are rare ecosystems in Saharan areas, we chose these wetlands as a key habitat model to assess plant biodiversity, within the general context of arid regions.

The aim of this study was to describe the characteristics of soil and vegetation and to establish the relationships between soil factors and plant species in saline wetlands of the arid Oued Righ region.

\section{Materials and methods}

\subsection{Study area}

The study area, including five saline wetland sites $\left(32^{\circ} 53^{\prime}-34^{\circ} 10^{\prime} \mathrm{N}, 05^{\circ} 47^{\prime}-06^{\circ} 10^{\prime} \mathrm{E} ; 27-70 \mathrm{~m}\right.$ asl), is located in the region of Oued Righ, a low basin of the northeastern Algeria, which is a part of Sahara Desert. The region covers an area of about $6 \times 10^{5} \mathrm{~km}^{2}$. The Oued Righ region extends about $160 \mathrm{~km}$ from El Goug in the south to Oum Tiour in the north with an average width ranging between 15 and $30 \mathrm{~km}$ (Bisson, 2003). As a whole, the Oued Righ region is characterized by a desert climate. It is emphasized that this type of climate is characterized by significant thermal amplitude and strong, bright sunshine, with the average annual sunshine of 3,000 h (Khadraoui, 2005). Precipitation is scarce and exhibits a considerable annual variability (Dubief, 1953; Ozenda, 1991). During 1984-2011, the average annual precipitation did not exceed $90 \mathrm{~mm}$ and the annual average temperature was $22.2^{\circ} \mathrm{C}$ with the minimum of $10.6^{\circ} \mathrm{C}$ in January and the maximum of $34.2^{\circ} \mathrm{C}$ in July. Annual average relative humidity ranges around $44.8 \%$ and annual average wind speed is $3.1 \mathrm{~m} / \mathrm{s}$. Vegetation and soil samples were collected over the four seasons of the two years (2009-2011). Five saline wetland sites were selected in our study, i.e. four lakes (Temacine, Merdjaja, Megarine and Ayata) and one chott (Sidi Slimane) (Fig. 1).

\subsection{Data collection}

The vegetation around each saline wetland was sampled along 4 transects with similar micro-topographic outlines extending perpendicularly to the water's edge. The dimensions of the rectangular quadrats (each having 4 sub-quadrats with an area of $5 \mathrm{~m} \times 5 \mathrm{~m}$ separated by a distance of $50 \mathrm{~cm}$ ) used to sample vegetation from each site along transect lines were $21.5 \mathrm{~m} \times 5 \mathrm{~m}$ (Rogel et al., 2001). We set the length of each transect with $21.5 \mathrm{~m}$ because there is no vegetation beyond the range. The quadrats were in fixed locations during the study period. We totally sampled 20 quadrats based on the formulation of Gounot (1969) for estimating various quantitative parameters such as number of plants per species (density) and vegetation cover in each quadrat $\left(100 \mathrm{~m}^{2}\right)$. We determined the identification of species and nomenclature of the plant taxa according to the studies of Quézel and Santa (1962), Chehma (2006), Halis (2007) and Kherraze et al. (2010). We collected soil samples from the $0-30 \mathrm{~cm}$ layer, based on the depth of the root zone of halophytic desert plants, which is generally distributed between 15 and $30 \mathrm{~cm}$ (Slimani, 2008). For each quadrat, we 
collected 16 soil samples every season for two years. Three cores for each sample were taken and mixed. We did not differentiate the soil into different soil depths because the soil is homogeneous at the $0-35 \mathrm{~cm}$ layer in the region of Oued Righ (Halitim et al., 2003). In total, 128 soil samples were taken at each site. Measured soil properties included electrical conductivity (EC, which was determined by an electrical conductivity meter in the 1:5 soil:water extraction) (Aubert, 1978), gravimetric moisture (which was determined by oven drying overnight at a temperature of $104^{\circ} \mathrm{C}$ ) and $\mathrm{pH}$ (which was determined by a $\mathrm{pH}$ meter (pHep HI 98107 HANNA, French) in the 1:2.5 soil:water extraction). The soluble anions and cations were determined in the 1:5 soil:water extraction. Soluble sodium, potassium, calcium and magnesium were measured by a flame photometer (Richards, 1954). Carbonate and bicarbonate contents of soil samples were determined by titration with $\mathrm{H}_{2} \mathrm{SO}_{4}$ (AFNOR, 1999); chloride content was determined by titration with $\mathrm{AgNO}_{3}{ }^{-}$(Richards, 1954); sulphates were determined by gravimetric method; and nitrate content was determined by a spectrophotometer. The gypsum content was determined according to the method of Viellefon (1979); total calcium carbonate was determined by Bernad's calcimeter (Aubert, 1978). Soil organic matter (OM) was determined by oxidation with $\mathrm{Cr}_{2} \mathrm{O}_{7} \mathrm{~K}_{2}$ in a sulphuric environment according to the Anne's method (Duchaufour, 1977).

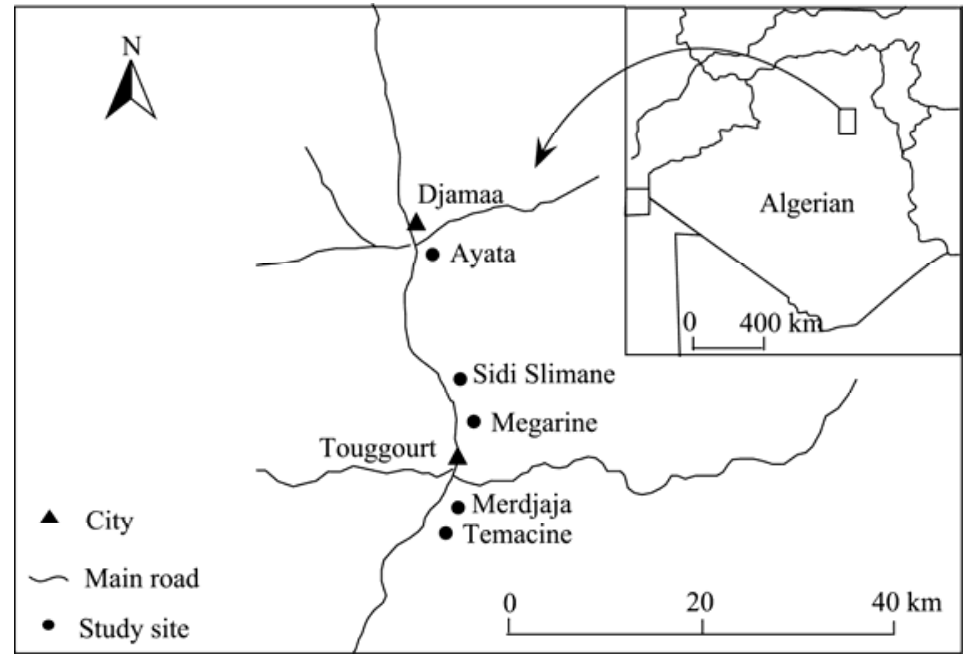

Fig. 1 Sketch map of the study sites

\subsection{Data analysis}

We analyzed the data collected in this study using the Statistica 6.0 software, and also used Canonical Correspondence Analysis (CCA) and Pearson correlation analysis to analyze the relationship between soil and vegetation.

\section{Results and discussion}

\subsection{Soil characteristics}

Soil characteristics in the study area are presented in Table 1. Soil analysis showed that the studied wetlands are characterized by 'salt-affected' to 'highly salt-affected' soils according to Aubert (1978). The unusually large values of EC reflected the existence of overlying salt crusts. The main factors leading to the formation of these crusts are the aridity, high evaporation and salty groundwater. The variation of the salinity between soils can be explained by the dynamics of saline groundwater imposed by the geomorphic conditions and climate of the region. Soil salinity reached its maximal value (EC of $18.27 \mathrm{dS} / \mathrm{m}$ ) in Sidi Slimane during the hot summer months (Table 1). In effect, the salinity was very variable in space and, for the same soil type in time, i.e. from one season to another. However, these variations are caused by different factors, including climate, topography, biota, groundwater depth, etc. Barrett (2006) indicated that soil 
Table 1 Seasonal changes of soil characteristics in the five wetland sites

\begin{tabular}{|c|c|c|c|c|c|c|}
\hline \multirow{2}{*}{ Soil property } & \multirow{2}{*}{ Season } & \multicolumn{5}{|c|}{ Wetland site } \\
\hline & & Ayata & Megarine & Merdjaja & Sidi Slimane & Temacine \\
\hline \multirow[t]{4}{*}{$\mathrm{EC}(\mathrm{dS} / \mathrm{m})$} & Autumn & $13.88 \pm 0.26$ & $8.03 \pm 0.27$ & $4.91 \pm 0.27$ & $17.89 \pm 0.45$ & $8.62 \pm 0.45$ \\
\hline & Winter & $12.14 \pm 0.06$ & $7.00 \pm 0.32$ & $4.48 \pm 0.17$ & $16.54 \pm 0.45$ & $7.90 \pm 0.45$ \\
\hline & Spring & $11.27 \pm 0.57$ & $7.66 \pm 0.01$ & $4.73 \pm 0.11$ & $16.97 \pm 0.39$ & $8.31 \pm 0.39$ \\
\hline & Summer & $13.41 \pm 0.02$ & $8.59 \pm 0.04$ & $5.39 \pm 0.05$ & $18.27 \pm 1.02$ & $9.40 \pm 0.48$ \\
\hline \multirow[t]{4}{*}{$\mathrm{pH}$} & Autumn & $7.20 \pm 0.12$ & $7.59 \pm 0.05$ & $7.21 \pm 0.33$ & $7.17 \pm 0.31$ & $7.65 \pm 0.31$ \\
\hline & Winter & $6.95 \pm 0.04$ & $7.57 \pm 0.06$ & $6.88 \pm 0.06$ & $6.96 \pm 0.25$ & $7.54 \pm 0.05$ \\
\hline & Spring & $6.99 \pm 0.01$ & $7.62 \pm 0.08$ & $7.40 \pm 0.34$ & $7.16 \pm 0.33$ & $7.68 \pm 0.33$ \\
\hline & Summer & $7.16 \pm 0.19$ & $7.73 \pm 0.02$ & $7.64 \pm 0.01$ & $7.45 \pm 0.42$ & $7.75 \pm 0.10$ \\
\hline \multirow[t]{4}{*}{ Moisture (\%) } & Autumn & $13.76 \pm 0.04$ & $19.47 \pm 0.16$ & $14.34 \pm 0.42$ & $23.06 \pm 1.29$ & $15.43 \pm 0.15$ \\
\hline & Winter & $15.88 \pm 0.25$ & $22.19 \pm 0.44$ & $16.78 \pm 0.21$ & $28.77 \pm 0.52$ & $17.44 \pm 0.32$ \\
\hline & Spring & $16.23 \pm 0.17$ & $21.25 \pm 0.71$ & $17.01 \pm 0.17$ & $24.78 \pm 1.34$ & $16.64 \pm 0.66$ \\
\hline & Summer & $13.27 \pm 0.16$ & $19.03 \pm 0.50$ & $14.56 \pm 0.48$ & $20.02 \pm 1.02$ & $15.11 \pm 0.81$ \\
\hline \multirow[t]{4}{*}{$\mathrm{CaSO}_{4}(\%)$} & Autumn & $24.23 \pm 0.19$ & $35.65 \pm 0.55$ & $19.75 \pm 0.10$ & $45.23 \pm 1.50$ & $35.00 \pm 0.54$ \\
\hline & Winter & $24.40 \pm 0.02$ & $34.24 \pm 0.14$ & $19.50 \pm 0.07$ & $45.26 \pm 0.56$ & $33.88 \pm 0.53$ \\
\hline & Spring & $24.38 \pm 0.01$ & $33.99 \pm 0.31$ & $19.42 \pm 0.02$ & $45.16 \pm 0.75$ & $33.66 \pm 0.67$ \\
\hline & Summer & $24.50 \pm 0.06$ & $35.26 \pm 0.14$ & $19.67 \pm 0.06$ & $45.35 \pm 0.98$ & $34.60 \pm 1.18$ \\
\hline \multirow[t]{4}{*}{$\mathrm{CaCO}_{3}(\%)$} & Autumn & $2.53 \pm 0.01$ & $3.02 \pm 0.17$ & $2.54 \pm 0.39$ & $4.65 \pm 0.33$ & $4.65 \pm 0.28$ \\
\hline & Winter & $2.52 \pm 0.25$ & $3.19 \pm 0.13$ & $2.84 \pm 0.01$ & $4.85 \pm 0.49$ & $4.77 \pm 0.11$ \\
\hline & Spring & $2.39 \pm 0.10$ & $3.07 \pm 0.03$ & $2.82 \pm 0.03$ & $4.81 \pm 0.32$ & $4.72 \pm 0.28$ \\
\hline & Summer & $2.58 \pm 0.02$ & $3.27 \pm 0.05$ & $2.88 \pm 0.03$ & $4.90 \pm 0.25$ & $4.82 \pm 0.16$ \\
\hline \multirow[t]{4}{*}{ OM (\%) } & Autumn & $2.77 \pm 0.07$ & $1.40 \pm 0.02$ & $4.07 \pm 0.04$ & $3.68 \pm 0.21$ & $1.40 \pm 0.06$ \\
\hline & Winter & $2.77 \pm 0.02$ & $1.46 \pm 0.05$ & $4.09 \pm 0.04$ & $3.79 \pm 0.16$ & $1.44 \pm 0.03$ \\
\hline & Spring & $2.85 \pm 0.03$ & $1.53 \pm 0.17$ & $4.12 \pm 0.08$ & $3.83 \pm 0.30$ & $1.45 \pm 0.52$ \\
\hline & Summer & $2.85 \pm 0.04$ & $1.54 \pm 0.21$ & $4.14 \pm 0.07$ & $3.85 \pm 0.08$ & $1.48 \pm 0.28$ \\
\hline \multirow[t]{4}{*}{$\mathrm{Cl}^{-}(\mathrm{mmol} / \mathrm{L})$} & Autumn & $65.46 \pm 0.05$ & $39.29 \pm 1.23$ & $14.97 \pm 0.35$ & $50.28 \pm 1.45$ & $35.82 \pm 1.05$ \\
\hline & Winter & $61.06 \pm 0.21$ & $36.02 \pm 0.11$ & $13.29 \pm 0.01$ & $46.18 \pm 1.20$ & $32.21 \pm 0.69$ \\
\hline & Spring & $61.80 \pm 0.95$ & $37.49 \pm 0.97$ & $12.79 \pm 0.17$ & $43.26 \pm 0.54$ & $33.53 \pm 0.98$ \\
\hline & Summer & $64.95 \pm 0.89$ & $40.56 \pm 0.12$ & $14.91 \pm 0.11$ & $49.23 \pm 1.02$ & $36.87 \pm 1.02$ \\
\hline \multirow[t]{4}{*}{$\mathrm{SO}_{4}^{2-}(\mathrm{mmol} / \mathrm{L})$} & Autumn & $2.99 \pm 0.20$ & $6.00 \pm 0.02$ & $2.15 \pm 0.08$ & $5.05 \pm 0.11$ & $5.85 \pm 0.07$ \\
\hline & Winter & $2.57 \pm 0.02$ & $5.67 \pm 0.03$ & $1.93 \pm 0.05$ & $4.92 \pm 0.14$ & $5.55 \pm 0.09$ \\
\hline & Spring & $2.75 \pm 0.05$ & $5.57 \pm 0.07$ & $1.94 \pm 0.03$ & $4.55 \pm 0.09$ & $5.51 \pm 0.14$ \\
\hline & Summer & $3.24 \pm 0.14$ & $5.96 \pm 0.10$ & $2.26 \pm 0.12$ & $5.05 \pm 0.13$ & $5.83 \pm 0.45$ \\
\hline \multirow[t]{4}{*}{$\mathrm{HCO}_{3}^{-}(\mathrm{mmol} / \mathrm{L})$} & Autumn & $13.72 \pm 0.48$ & $18.01 \pm 0.02$ & $18.88 \pm 0.59$ & $29.86 \pm 1.20$ & $19.05 \pm 0.77$ \\
\hline & Winter & $11.66 \pm 0.06$ & $17.24 \pm 0.09$ & $18.13 \pm 0.15$ & $26.52 \pm 0.59$ & $18.46 \pm 0.95$ \\
\hline & Spring & $10.50 \pm 0.72$ & $17.44 \pm 0.01$ & $18.59 \pm 0.28$ & $24.10 \pm 2.01$ & $18.61 \pm 1.06$ \\
\hline & Summer & $12.80 \pm 0.52$ & $18.09 \pm 0.22$ & $19.57 \pm 0.23$ & $27.73 \pm 1.63$ & $19.40 \pm 1.20$ \\
\hline \multirow[t]{4}{*}{$\mathrm{NO}_{3}^{-}(\mathrm{mmol} / \mathrm{L})$} & Autumn & $0.29 \pm 0.04$ & $0.35 \pm 0.02$ & $0.19 \pm 0.03$ & $0.19 \pm 0.01$ & $0.20 \pm 0.02$ \\
\hline & Winter & $0.30 \pm 0.01$ & $0.31 \pm 0.01$ & $0.17 \pm 0.06$ & $0.17 \pm 0.02$ & $0.19 \pm 0.03$ \\
\hline & Spring & $0.31 \pm 0.01$ & $0.29 \pm 0.01$ & $0.17 \pm 0.05$ & $0.18 \pm 0.02$ & $0.20 \pm 0.01$ \\
\hline & Summer & $0.33 \pm 0.02$ & $0.30 \pm 0.02$ & $0.18 \pm 0.05$ & $0.22 \pm 0.05$ & $0.22 \pm 0.04$ \\
\hline \multirow[t]{4}{*}{$\mathrm{Ca}^{2+}(\mathrm{mmol} / \mathrm{L})$} & Autumn & $17.68 \pm 0.46$ & $16.15 \pm 0.31$ & $31.69 \pm 0.33$ & $44.46 \pm 0.60$ & $16.25 \pm 0.10$ \\
\hline & Winter & $16.05 \pm 0.08$ & $15.44 \pm 0.11$ & $30.36 \pm 0.41$ & $43.08 \pm 0.47$ & $15.80 \pm 0.20$ \\
\hline & Spring & $15.55 \pm 0.26$ & $15.94 \pm 0.06$ & $30.97 \pm 0.32$ & $43.02 \pm 0.64$ & $15.92 \pm 0.31$ \\
\hline & Summer & $17.34 \pm 0.14$ & $16.41 \pm 0.18$ & $32.06 \pm 0.50$ & $45.16 \pm 0.60$ & $16.48 \pm 0.50$ \\
\hline \multirow[t]{4}{*}{$\mathrm{Mg}^{2+}(\mathrm{mmol} / \mathrm{L})$} & Autumn & $3.09 \pm 0.33$ & $5.57 \pm 0.02$ & $0.77 \pm 0.03$ & $2.28 \pm 0.15$ & $6.25 \pm 0.46$ \\
\hline & Winter & $2.27 \pm 0.13$ & $5.03 \pm 0.09$ & $0.74 \pm 0.02$ & $2.17 \pm 0.03$ & $5.74 \pm 0.38$ \\
\hline & Spring & $1.86 \pm 0.26$ & $5.18 \pm 0.08$ & $0.74 \pm 0.02$ & $2.18 \pm 0.05$ & $5.95 \pm 0.50$ \\
\hline & Summer & $2.85 \pm 0.03$ & $5.60 \pm 0.02$ & $0.84 \pm 0.04$ & $2.45 \pm 0.25$ & $6.42 \pm 0.43$ \\
\hline \multirow[t]{4}{*}{$\mathrm{Na}^{+}(\mathrm{mmol} / \mathrm{L})$} & Autumn & $24.71 \pm 0.60$ & $23.16 \pm 0.32$ & $9.70 \pm 0.89$ & $19.98 \pm 1.06$ & $20.79 \pm 0.45$ \\
\hline & Winter & $22.46 \pm 0.19$ & $22.13 \pm 0.01$ & $9.49 \pm 0.33$ & $18.75 \pm 0.34$ & $20.34 \pm 0.31$ \\
\hline & Spring & $21.65 \pm 0.64$ & $22.35 \pm 0.03$ & $9.92 \pm 0.08$ & $20.01 \pm 0.50$ & $20.32 \pm 1.18$ \\
\hline & Summer & $24.07 \pm 0.01$ & $23.61 \pm 0.07$ & $10.43 \pm 0.74$ & $21.31 \pm 0.68$ & $20.93 \pm 0.78$ \\
\hline \multirow[t]{4}{*}{$\mathrm{K}^{+}(\mathrm{mmol} / \mathrm{L})$} & Autumn & $0.55 \pm 0.03$ & $1.26 \pm 0.04$ & $0.20 \pm 0.06$ & $0.65 \pm 0.03$ & $1.77 \pm 0.06$ \\
\hline & Winter & $0.46 \pm 0.01$ & $1.18 \pm 0.02$ & $0.18 \pm 0.02$ & $0.57 \pm 0.04$ & $1.68 \pm 0.10$ \\
\hline & Spring & $0.43 \pm 0.04$ & $1.24 \pm 0.05$ & $0.22 \pm 0.04$ & $0.50 \pm 0.07$ & $1.70 \pm 0.10$ \\
\hline & Summer & $0.54 \pm 0.02$ & $1.33 \pm 0.05$ & $0.25 \pm 0.02$ & $0.63 \pm 0.03$ & $1.81 \pm 0.12$ \\
\hline
\end{tabular}

Note: Mean \pm SD. EC, electrical conductivity; OM, organic matter.

salinity is strongly influenced by the depth of groundwater and soil texture in salt lakes of the semi-arid regions. In this study, soil moisture varied between $13.27 \%$ and $28.77 \%$ for all studied 
sites (Table 1). It varied from one season to another and increased gradually from autumn to spring due to the increase of water content related to the groundwater depth. After that, the moisture decreased due to the high evaporation rate during the summer period (Halitim, 1988). Soil $\mathrm{pH}$ in the studied soils ranged from 6.88 to 7.75 and were neutral to alkaline according to Soltner (1989). Soil analysis indicated the dominance of the chloride anion and calcium cation in soil solutions for the four seasons. However, there was a significant variation in soluble salts throughout the seasons relating directly to soil salinity.

The soil gypsum was important for all studied wetlands. In this study, soils were classified as moderately to extremely gypsiferous. The soils of the Sidi Slimane Chott contained the most gypsum with the content $>45 \%$. The temporal variation of gypsum is linked to the permanent process of dissolution/re-precipitation of gypsum in the soil system (Hamdi-Aissa et al., 2004). As well, we noted a temporal variation of calcareous content of soils, which is influenced by the fluctuation of groundwater depth under arid climatic conditions. The studied soils were characterized by a few calcareous with $2 \%$ to $5 \%$ calcium content. With regard to OM content, the studied soils were generally classified as 'low' to 'medium' rich in OM (1.40\% to $4.14 \%)$. We observed a spatial variation in $\mathrm{OM}$ content, which is directly related to the vegetation cover. However, the temporal variation in OM was not significant. In general, the variations in soil characteristics were a function of precipitation/dissolution and oxidation-reduction processes in this type of environment, which is often flooded for long periods during the year.

\subsection{Vegetation characteristics}

There were 17 plant species belonging to seven families in the study area (Table 2), presented by 16 perennials species and 1 ephemeral species. The natural vegetation of the studied saline wetlands was composed of halophytic and hydro-halophytic plant communities. Khan (1990) indicated that saline habitats are characterized by a specific plant community, especially in the deserts. The chamaephytes were the major life-form in the studied sites, accounting for $41 \%$ of all species. They were represented especially by the species of Amaranthaceae. The geophytes were represented by four species (23.5\% of all species). Moreover, therophytes, helophytes and phanerophytes had the same number of species ( 2 species for each).

Table 2 Plant species and life forms in the study area

\begin{tabular}{ccc}
\hline Family & Plant species & Life form \\
\hline Amaranthaceae & Halocnemum strobilaceum & Chamaephyte \\
& Arthrocnemum glaucum & Chamaephyte \\
& Traganum nudatum & Chamaephyte \\
& Salicornia fructicosa & Chamaephyte \\
& Suaeda fructicosa & Chamaephyte \\
Juncaceae & Cornulaca monacantha & Helophyte \\
Poaceae & Juncus maritimus & Geophyte \\
& Aeluropus littoralis & Geophyte \\
& Cynodon dactylon & Helophyte \\
Asteraceae & Phragmites communis & Geophyte \\
Tamaricaceae & Sonchus maritimus & Phanerophyte \\
Zygophyllaceae & Tamarix gallica & Chamaephyte \\
Molluginaceae & Zygophyllum album & Therophyte \\
Plumbaginaceae & Mollugo nudicaulis & Phanerophyte \\
Convolvulaceae & Timoniastrum guyonianum & Therophyte \\
Orobanchaceae & Cressa cretica & Parasite
\end{tabular}

There was an absence of plants submerged or floating in the water. Both of the arid climate and unstable soil structure (sandy texture and particular structure with spaced particles) (Khadraoui, 2007) promoted the development of species with a short life cycle, especially the therophytes. However, the shallow saline groundwater favored the development of halophytes, especially the 
Amaranthaceae family, representing a good adaptation to environmental conditions (Le Houérou, 1992). The plant taxa in the study area have adaptations not only for high soil salinity but also for long arid summers, and most of them have xero-halophytic characteristics (Tug et al., 2012). The number of species recorded from the five studied sites was 10 species in Megarine and Ayata lakes, 8 species in Temacine Lake, 7 species in Merdjaja Lake and 6 species in Sidi Slimane Chott. According to Daget and Poissonet (1991), the floristic richness (number of species) for each habitat of our study area was classified as very poor. In the study on the marshes of Maryland, Darmody and Foss (1979) found that increasing salt content would lower the floristic richness.

The species density and vegetation cover of each wetland are presented in Table 3 . Sidi Slimane Chott presented the highest species density with the value of 12.33 plants $/ \mathrm{m}^{2}$, followed by Megarine $\left(7.14\right.$ plants $\left./ \mathrm{m}^{2}\right)$, Merdjaja $\left(5.44\right.$ plants $\left./ \mathrm{m}^{2}\right)$, Temacine $\left(5.34 \mathrm{plants} / \mathrm{m}^{2}\right)$ and Ayata (5.00 plants $\left./ \mathrm{m}^{2}\right)$. For vegetation cover, the Sidi Slimane Chott presented the highest value (40.88\%), followed by Ayata Lake (28.81\%), Merdjaja Lake (27.49\%), Megarine Lake (20.24\%) and Temacine Lake $(9.45 \%)$. The vegetation cover also varied seasonally. Moreover, this variation was directly related to the floristic cycle and the mode of adaptation of the desert species (Ozenda, 1991), which depended upon the climatic conditions (Gardi, 1973; Poupon, 1980).

\subsection{Soil-vegetation relationship}

The habitats of Oued Righ showed fluctuations in soil moisture and salinity throughout the year. The saline soils of the study area caused a great stress on the biological diversity, and only species with adaptations to tolerate this harsh environment can survive. In this study, we used the CCA to determine the environmental factors influencing the distribution of vegetation in the saline wetlands, based only on the vegetation cover (Table 4). According to the CCA results, the first component axis explained $67.343 \%$ of the total variance. The first and second components explained $84.901 \%$ of the total variance. Soil variables related to the first component axis were $\mathrm{EC}$, moisture, $\mathrm{SO}_{4}{ }^{2-}$ and $\mathrm{Ca}^{2+}$, while the second axis was related to $\mathrm{EC}, \mathrm{Cl}^{-}, \mathrm{K}^{+}$and $\mathrm{CaSO}_{4}($ Table 5). Plant species in the CCA diagram can be classified into five groups (Fig. 2).

Group I, on the positive side of axis 1, comprised two species (i.e. Phragmites communis and Juncus maritimus) distributed mainly in Sidi Slimane Chott. This site was characterized by very salty, humid and gypsiferous soils which explained the significant positive correlation of $P$. communis and $\mathrm{J}$. maritimus with soil EC, moisture and $\mathrm{CaSO}_{4}$ located in the same side of the CCA diagram (Fig. 2; Table 6). Rogel et al. (2000) pointed out that J. maritimus grows in long-term flooded soils with high salinity. Group II, on the lower positive side of axis 1 (Fig. 2), comprised Zygophyllum album, Limoniastrum guyonianum, Cornulaca monacantha and Cistanche tinctoria. These species are mainly distributed in Merdjaj Lake. They were negatively correlated with soil salinity, moisture and gypsum (Table 6), and positively correlated with $\mathrm{Ca}^{2+}$ and OM situated in the same side of the CCA graph (Fig. 2). We found that soils in Merdjaja Lake were poorest in soil salinity, moisture and gypsum, but were richest in $\mathrm{OM}$ and $\mathrm{Ca}^{2+}$. Group III, on the negative side of axis 1, included Aeluropus littoralis, Cynodon dactylon, Sonchus maritimus, Mollugo nudicaulis and Suaeda fructicosa. These species presented a significant negative correlation with soil salinity (Table 6), which explains their absence from the most salty soils in Sidi Slimane Chott and Ayata Lake. Group IV, distributed in the upper central part of the graph, comprised three species, i.e. Salicornia fructicosa, Traganum nudatum and Arthrocnemum glaucum. These species were positively correlated with soil salinity and negatively correlated with soil moisture and $\mathrm{pH}$ (Table 6). These species are distributed only in Ayata Lake. Group V was located in the center of the graph and comprised Halocnemum strobilaceum, Tamarix gallica and Cressa cretica. H. strobilaceum and T. gallica are widely distributed in all studied wetlands. $H$. strobilaceum was significantly correlated with soil salinity and moisture (Table 6). It is known to be well adapted to salinity and drought. Chighani et al. (2010) indicated that $\mathrm{CaSO}_{4}$, percentage of clay, $\mathrm{K}^{+}$, salinity and alkalinity of soils have positive effects on the habitat of $H$. strobilaceum.

The distribution of plant species along the CCA axis revealed that the spatial distribution of vegetation between the saline habitats and surrounding water's edge is not coincidental. It caused by the interaction of environmental variables, including soil characteristics (EC, moisture, CaSO4, 
Table 3 Density (Dt; plants $\left./ \mathrm{m}^{2}\right)$ and cover (C; \%) of plant species in different seasons in the five wetland sites

\begin{tabular}{|c|c|c|c|c|c|c|c|c|c|c|c|}
\hline \multirow{3}{*}{ Plant species } & \multirow{3}{*}{ Season } & \multicolumn{10}{|c|}{ Wetland site } \\
\hline & & \multicolumn{2}{|c|}{ Ayata } & \multicolumn{2}{|c|}{ Megarine } & \multicolumn{2}{|c|}{ Merdjaja } & \multicolumn{2}{|c|}{ Sidi Slimane } & \multicolumn{2}{|c|}{ Temacine } \\
\hline & & $\mathrm{Dt}$ & $\mathrm{C}$ & $\mathrm{Dt}$ & $\mathrm{C}$ & $\mathrm{Dt}$ & $\mathrm{C}$ & Dt & $\mathrm{C}$ & $\mathrm{Dt}$ & $\mathrm{C}$ \\
\hline \multirow[t]{4}{*}{ P. communis } & Autumn & 101.81 & 0.71 & 68.53 & 0.48 & 113.13 & 0.79 & 286.03 & 2.01 & 97.34 & 0.68 \\
\hline & Winter & 104.53 & 0.74 & 76.34 & 0.56 & 117.00 & 0.82 & 291.00 & 2.05 & 101.09 & 0.71 \\
\hline & Spring & 106.63 & 0.75 & 81.19 & 0.57 & 118.59 & 0.84 & 291.50 & 2.08 & 103.22 & 0.73 \\
\hline & Summer & 105.59 & 0.73 & 81.19 & 0.57 & 118.59 & 0.81 & 288.53 & 2.00 & 102.19 & 0.71 \\
\hline \multirow[t]{4}{*}{ J. maritimus } & Autumn & 1.56 & 0.23 & 2.97 & 0.55 & I & I & 15.81 & 6.90 & 1.81 & 0.34 \\
\hline & Winter & 1.59 & 0.24 & 3.06 & 0.55 & / & / & 15.97 & 6.92 & 1.91 & 0.35 \\
\hline & Spring & 1.66 & 0.25 & 3.09 & 0.57 & l & l & 15.97 & 7.05 & 1.91 & 0.37 \\
\hline & Summer & 1.66 & 0.27 & 3.09 & 0.57 & / & l & 15.97 & 7.03 & 1.91 & 0.38 \\
\hline \multirow[t]{4}{*}{ T. gallica } & Autumn & 0.44 & 0.44 & 0.63 & 0.55 & 0.38 & 0.62 & 0.13 & 0.82 & 0.44 & 0.22 \\
\hline & Winter & 0.44 & 0.44 & 0.63 & 0.55 & 0.38 & 0.62 & 0.13 & 0.82 & 0.44 & 0.22 \\
\hline & Spring & 0.44 & 0.44 & 0.63 & 0.57 & 0.38 & 0.70 & 0.13 & 0.82 & 0.44 & 0.23 \\
\hline & Summer & 0.44 & 0.44 & 0.63 & 0.57 & 0.38 & 0.69 & 0.13 & 0.82 & 0.44 & 0.23 \\
\hline \multirow[t]{4}{*}{ H. strobilaceum } & Autumn & 5.16 & 1.29 & 4.06 & 1.84 & 5.00 & 1.34 & 1.13 & 0.27 & 1.19 & 0.52 \\
\hline & Winter & 5.16 & 1.29 & 4.13 & 1.85 & 5.09 & 1.34 & 1.19 & 0.28 & 1.28 & 0.52 \\
\hline & Spring & 5.19 & 1.31 & 4.13 & 1.86 & 5.16 & 1.35 & 1.19 & 0.30 & 1.28 & 0.54 \\
\hline & Summer & 5.19 & 1.31 & 4.13 & 1.86 & 5.16 & 1.35 & 1.19 & 0.30 & 1.28 & 0.54 \\
\hline \multirow[t]{4}{*}{ S. fructicosa } & Autumn & 0.78 & 0.18 & 1.13 & 0.19 & I & l & 0.13 & 0.02 & 0.25 & 0.11 \\
\hline & Winter & 0.78 & 0.18 & 1.13 & 0.19 & I & / & 0.13 & 0.02 & 0.25 & 0.11 \\
\hline & Spring & 0.81 & 0.19 & 1.13 & 0.20 & l & I & 0.13 & 0.02 & 0.25 & 0.14 \\
\hline & Summer & 0.84 & 0.19 & 1.13 & 0.20 & l & l & 0.13 & 0.02 & 0.25 & 0.14 \\
\hline \multirow[t]{4}{*}{ Z. album } & Autumn & 1.50 & 0.18 & I & I & 7.63 & 1.46 & / & I & I & I \\
\hline & Winter & 1.50 & 0.18 & I & / & 7.63 & 1.47 & / & / & I & / \\
\hline & Spring & 1.53 & 0.18 & I & / & 7.88 & 1.49 & / & I & I & / \\
\hline & Summer & 1.53 & 0.18 & I & / & 7.88 & 1.48 & / & I & / & / \\
\hline \multirow[t]{4}{*}{ L. guyonianum } & Autumn & 0.25 & 0.15 & I & / & 4.56 & 2.46 & / & I & I & / \\
\hline & Winter & 0.25 & 0.15 & I & / & 4.56 & 2.47 & I & I & I & / \\
\hline & Spring & 0.25 & 0.14 & I & I & 4.69 & 2.48 & / & I & I & / \\
\hline & Summer & 0.25 & 0.14 & I & I & 4.69 & 2.48 & l & I & / & / \\
\hline \multirow[t]{4}{*}{ C. monacantha } & Autumn & l & / & I & / & 0.94 & 0.10 & / & I & I & / \\
\hline & Winter & l & I & I & l & 0.94 & 0.10 & I & I & I & / \\
\hline & Spring & / & / & 1 & / & 1.00 & 0.11 & / & 1 & I & / \\
\hline & Summer & / & / & I & / & 1.00 & 0.11 & I & I & I & / \\
\hline \multirow[t]{4}{*}{ C. tinctoria } & Autumn & l & I & I & l & 0.00 & 0.00 & l & I & I & / \\
\hline & Winter & I & / & I & / & 0.00 & 0.00 & / & I & I & / \\
\hline & Spring & I & I & I & / & 0.84 & 0.01 & / & I & I & / \\
\hline & Summer & I & I & l & I & 0.00 & 0.00 & / & I & I & / \\
\hline C. cretica & Autumn & / & / & 0.63 & 0.05 & l & l & 2.19 & 0.07 & I & / \\
\hline & Winter & / & / & 0.63 & 0.05 & l & l & 2.19 & 0.07 & I & l \\
\hline & Spring & I & / & 0.63 & 0.05 & l & / & 2.19 & 0.07 & I & / \\
\hline & Summer & I & I & 0.63 & 0.05 & I & / & 2.19 & 0.07 & I & I \\
\hline M. nudicaulis & Autumn & I & / & 0.94 & 0.07 & l & l & l & I & 0.38 & 0.04 \\
\hline & Winter & I & / & 0.97 & 0.07 & / & / & l & I & 0.44 & 0.04 \\
\hline & Spring & I & I & 0.97 & 0.07 & l & / & / & I & 0.44 & 0.04 \\
\hline & Summer & / & / & 0.97 & 0.07 & I & / & l & 1 & 0.44 & 0.04 \\
\hline S. fructicosa & Autumn & 9.09 & 2.80 & I & I & / & / & I & I & I & / \\
\hline & Winter & 9.09 & 2.80 & I & l & l & l & l & I & I & / \\
\hline & Spring & 9.09 & 2.84 & I & l & l & l & l & I & I & / \\
\hline & Summer & 9.09 & 2.84 & I & l & l & l & l & I & I & / \\
\hline T. nudatum & Autumn & 0.78 & 0.59 & I & / & l & I & / & I & I & / \\
\hline & Winter & 0.78 & 0.59 & I & l & l & l & I & I & I & l \\
\hline
\end{tabular}


Continued

\begin{tabular}{|c|c|c|c|c|c|c|c|c|c|c|c|}
\hline \multirow{3}{*}{ Plant species } & \multirow{3}{*}{ Season } & \multicolumn{10}{|c|}{ Wetland site } \\
\hline & & \multicolumn{2}{|c|}{ Ayata } & \multicolumn{2}{|c|}{ Megarine } & \multicolumn{2}{|c|}{ Merdjaja } & \multicolumn{2}{|c|}{ Sidi Slimane } & \multicolumn{2}{|c|}{ Temacine } \\
\hline & & $\mathrm{Dt}$ & $\mathrm{C}$ & $\mathrm{Dt}$ & $\mathrm{C}$ & $\mathrm{Dt}$ & $\mathrm{C}$ & $\mathrm{Dt}$ & $\mathrm{C}$ & $\mathrm{Dt}$ & $\mathrm{C}$ \\
\hline \multirow{6}{*}{ A. glaucum } & Spring & 0.81 & 0.60 & 1 & 1 & 1 & 1 & 1 & 1 & 1 & 1 \\
\hline & Summer & 0.81 & 0.60 & / & I & / & / & I & 1 & / & / \\
\hline & Autumn & 0.72 & 0.56 & / & / & / & / & I & 1 & / & / \\
\hline & Winter & 0.72 & 0.56 & / & I & / & / & I & 1 & / & / \\
\hline & Spring & 0.72 & 0.57 & / & I & / & / & I & l & I & / \\
\hline & Summer & 0.72 & 0.57 & / & I & 1 & 1 & I & 1 & / & / \\
\hline \multirow{4}{*}{ A. littoralis } & Autumn & / & l & 84.13 & 0.84 & 1 & 1 & I & 1 & 27.25 & 0.27 \\
\hline & Winter & / & I & 84.13 & 0.84 & / & / & I & l & 27.38 & 0.28 \\
\hline & Spring & / & / & 84.75 & 0.85 & 1 & / & I & 1 & 28.69 & 0.29 \\
\hline & Summer & / & l & 84.75 & 0.84 & / & 1 & / & l & 28.69 & 0.28 \\
\hline \multirow[t]{4}{*}{ C. dactylon } & Autumn & / & I & 4.34 & 0.30 & 1 & / & I & 1 & 1.25 & 0.09 \\
\hline & Winter & I & l & 4.75 & 0.32 & 1 & / & I & 1 & 1.44 & 0.10 \\
\hline & Spring & / & l & 4.91 & 0.34 & 1 & / & I & 1 & 1.50 & 0.11 \\
\hline & Summer & I & / & 4.91 & 0.33 & 1 & / & I & 1 & 1.50 & 0.10 \\
\hline \multirow[t]{4}{*}{ S. maritimus } & Autumn & I & I & I & I & / & / & I & l & 1.91 & 0.05 \\
\hline & Winter & I & I & / & / & / & / & I & 1 & 2.09 & 0.06 \\
\hline & Spring & I & I & / & I & / & / & I & 1 & 2.19 & 0.07 \\
\hline & Summer & l & l & I & l & / & / & I & I & 2.19 & 0.06 \\
\hline
\end{tabular}

Note: “/" means no data available (absence of plant).

Table 4 Variance of component axes following the Canonical Correspondence Analysis (CCA)

\begin{tabular}{ccccc}
\hline & \multicolumn{4}{c}{ Component axis } \\
\cline { 2 - 5 } & 1 & 2 & 3 & 4 \\
\hline Percentage of variance (\%) & 67.343 & 17.558 & 13.679 & 1.420 \\
Cumulative percentage of variance (\%) & 67.343 & 84.901 & 98.580 & 100 \\
\hline
\end{tabular}

Table 5 Loading values of variations explaining each axis of the components

\begin{tabular}{|c|c|c|c|c|}
\hline \multirow{2}{*}{ Variable } & \multicolumn{4}{|c|}{ Component axis } \\
\hline & 1 & 2 & 3 & 4 \\
\hline $\mathrm{EC}$ & $0.713^{*}$ & $0.978^{*}$ & -0.200 & -0.297 \\
\hline $\mathrm{pH}$ & -0.224 & -0.151 & 0.084 & 0.014 \\
\hline Moisture & 0.576 & 0.278 & 0.326 & -0.370 \\
\hline $\mathrm{Cl}^{-}$ & 0.170 & $0.540^{*}$ & -0.176 & -0.074 \\
\hline $\mathrm{SO}_{4}{ }^{2-}$ & $-0.900^{*}$ & -0.345 & 0.573 & -0.412 \\
\hline $\mathrm{HCO}_{3}^{-}$ & 0.154 & -0.250 & 0.160 & 0.242 \\
\hline $\mathrm{NO}_{3}^{-}$ & -0.133 & -0.028 & -0.187 & -0.140 \\
\hline $\mathrm{Ca}^{2+}$ & $0.994^{*}$ & -0.270 & 0.431 & -0.123 \\
\hline $\mathrm{Mg}^{2+}$ & -0.357 & 0.246 & 0.373 & 0.123 \\
\hline $\mathrm{Na}^{+}$ & 0.057 & 0.387 & -0.176 & -0.049 \\
\hline $\mathrm{K}^{+}$ & -0.336 & $-0.884^{*}$ & -0.153 & 0.383 \\
\hline $\mathrm{CaSO}_{4}$ & 0.239 & $0.519^{*}$ & 0.151 & 0.526 \\
\hline $\mathrm{CaCO}_{3}$ & -0.163 & $0.340^{*}$ & 0.300 & 0.398 \\
\hline OM & 0.287 & -0.355 & -0.486 & 0.442 \\
\hline
\end{tabular}

Note: ${ }^{*}$ means significance at $P<0.05$ level. 


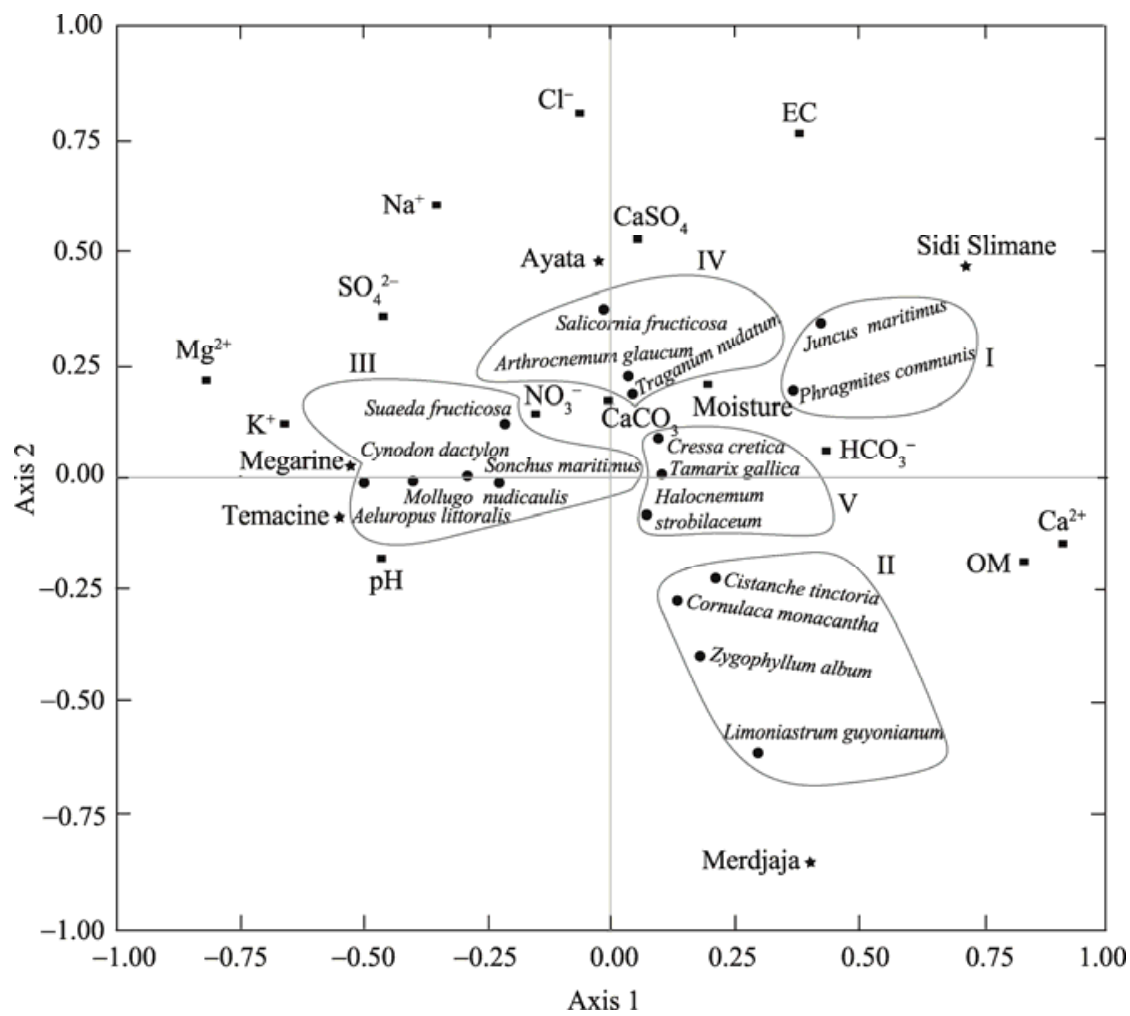

Fig. 2 CCA-ordination diagram of the plant species related to soil properties. EC, electrical conductivity; OM, organic matter.

$\mathrm{K}^{+}, \mathrm{Ca}^{2+}$ and $\mathrm{Cl}^{-}$) and climatic factors. According to the study of Brown (2006), the mosaic structure of zonal plants reflects the heterogeneity of environmental factors, mainly including soil moisture and salinity. Pedologically, the halophytes do not have strict requirements to colonize the edges of

sebkhas where the saline character is perceptible (Aboura et al., 2006). Koull and Chehma (2015) indicated that both soil salinity and moisture affect the distribution of vegetation in saline wetlands. This agrees with other studies which showed that these two variables have a strong influence on plant distribution in saline habitats (e.g. Rogel et al., 2000; Khaznadar et al., 2009; González-Alcaraz et al., 2014). Although there are many studies focused on the zonation of vegetation in saline habitats (Snow and Vince, 1984; Bertness and Ellison, 1987; Bertness, 1991a, b; Pennings and Callaway, 1992), the vegetation of saline habitats in arid areas is still poorly understood. As a result of these studies, we found that the distribution of vegetation is structured following a precise zonation pattern in the study area.

In this study, the species can be divided into several parallel belts surrounding the water's edge. $H$. strobilaceum belongs to the family of Amaranthaceae, which is known for having an effective mechanism to tolerate soil salinity and alkalinity (Alkhverdiev, 1988; Ayoub and Malcolm, 1993; Malcolm and Choukr-Allah, 1995; Abd El-Ghani and Amer, 2003). This species is distributed in environments with high levels of soil EC and moisture content, and forms the first belt surrounding the water body. P. communis is widely distributed in the study area with high density. The abundance of this species is probably favored by the drainage of agricultural waters with moderate salinity and high contents of nutrients (Arce et al., 2013). Thus, it is stimulated strongly by water and forms the mono-specific stands in saline wetland areas (Carreño et al., 2008). The species of J. maritimus, T. gallica and S. fructicosa partly or completely occupy the flooded soils in winter. The species S. fructicosa, T. nudatum, A. glaucum, A. littoralis, C. cretica and C. dactylon grow in salty and moist soils away from the water's edge. Z. album, L. guyonianum, $C$. monacantha, C. tinctoria, M. nudicaulis and S. maritimus, distributed in soils with less salinity and moisture, are far away from the water body. 
Table 6 Pearson correlation coefficients between plant species and soil characteristics

\begin{tabular}{|c|c|c|c|c|c|c|c|}
\hline & EC & $\mathrm{pH}$ & Moisture & $\mathrm{Cl}^{-}$ & $\mathrm{SO}_{4}^{2-}$ & $\mathrm{HCO}_{3}^{-}$ & $\mathrm{NO}_{3}^{-}$ \\
\hline P. communis & $0.294^{* *}$ & $-0.105^{* *}$ & $0.541^{* *}$ & $0.226^{* *}$ & -0.060 & $0.299^{* *}$ & 0.026 \\
\hline J. maritimus & $0.123^{* *}$ & $-0.089^{* *}$ & $0.269^{* *}$ & -0.016 & $0.075^{*}$ & $0.345^{* *}$ & $-0.164^{* *}$ \\
\hline T. gallica & 0.030 & -0.059 & 0.022 & $-0.081^{* *}$ & -0.040 & $0.077^{*}$ & -0.046 \\
\hline H. strobilaceum & $0.160^{* *}$ & -0.012 & $0.261^{* *}$ & $0.305^{* *}$ & $-0.067^{*}$ & -0.019 & $0.258^{* *}$ \\
\hline S. fructicosa & -0.055 & 0.042 & 0.052 & -0.022 & $0.128^{* *}$ & $-0.165^{* *}$ & $-0.099^{* *}$ \\
\hline Z. album & $-0.236^{* *}$ & -0.047 & $-0.267^{* *}$ & $-0.286^{* *}$ & $-0.244^{* *}$ & -0.049 & -0.045 \\
\hline L. guyonianum & $-0.277^{* *}$ & $-0.072^{*}$ & $-0.270^{* *}$ & $-0.355^{* *}$ & $-0.198^{* *}$ & $-0.140^{* *}$ & $-0.162^{* *}$ \\
\hline C. monacantha & $-0.160^{* *}$ & 0.013 & $-0.199^{* *}$ & $-0.236^{* *}$ & $-0.097^{* *}$ & -0.032 & -0.045 \\
\hline C. tinctoria & -0.017 & -0.018 & $-0.068^{*}$ & -0.030 & -0.037 & 0.005 & -0.048 \\
\hline C. cretica & 0.026 & $0.072^{*}$ & 0.050 & $-0.113^{* *}$ & $0.114^{* *}$ & -0.033 & 0.040 \\
\hline M. nudicaulis & $-0.120^{* *}$ & $0.094^{* *}$ & $-0.100^{* *}$ & $-0.105^{* *}$ & $0.144^{* *}$ & -0.058 & 0.012 \\
\hline S. fructicosa & $0.135^{* *}$ & $-0.253^{* *}$ & $-0.170^{* *}$ & $0.276^{* *}$ & -0.053 & $-0.380^{* *}$ & 0.049 \\
\hline T. nudatum & 0.035 & $-0.113^{* *}$ & $-0.159^{* *}$ & $0.219^{* *}$ & $-0.062^{*}$ & $-0.250^{* *}$ & 0.047 \\
\hline A. glaucum & 0.019 & $-0.101^{* *}$ & -0.059 & $0.098^{* *}$ & $-0.097^{* *}$ & $-0.159^{* *}$ & $0.106^{* *}$ \\
\hline A. littoralis & 0.034 & $0.248^{* *}$ & 0.036 & $0.164^{* *}$ & $0.168^{* *}$ & 0.021 & $0.239^{* *}$ \\
\hline C. dactylon & $-0.385^{* *}$ & $0.158^{* *}$ & $-0.078^{*}$ & $-0.075^{*}$ & $-0.125^{* *}$ & $0.149^{* *}$ & $-0.270^{* *}$ \\
\hline \multirow[t]{2}{*}{ S. maritimus } & $-0.337^{* *}$ & 0.060 & -0.004 & -0.024 & $-0.329^{* *}$ & $0.200^{* *}$ & $-0.326^{* *}$ \\
\hline & $\mathrm{Ca}^{2+}$ & $\mathrm{Mg}^{2+}$ & $\mathrm{Na}^{+}$ & $\mathrm{K}^{+}$ & $\mathrm{CaSO}_{4}$ & $\mathrm{CaCO}_{3}$ & $\mathrm{OM}$ \\
\hline P. communis & $0.076^{*}$ & $-0.268^{* *}$ & -0.059 & $-0.206^{* *}$ & $0.122^{* *}$ & $0.157^{* *}$ & $0.110^{* *}$ \\
\hline J. maritimus & $0.332^{* *}$ & $-0.101^{* *}$ & -0.010 & $-0.100^{* *}$ & $0.224^{* *}$ & $0.162^{* *}$ & $0.390^{* *}$ \\
\hline T. gallica & 0.020 & $-0.076^{*}$ & $-0.130^{* *}$ & $-0.111^{* *}$ & -0.030 & 0.018 & -0.011 \\
\hline H. strobilaceum & $-0.143^{* *}$ & $-0.151^{* *}$ & $0.073^{*}$ & $-0.092^{* *}$ & -0.059 & -0.040 & $-0.189^{* *}$ \\
\hline S. fructicosa & -0.027 & $0.189^{* *}$ & 0.040 & 0.050 & 0.038 & 0.010 & 0.028 \\
\hline Z. album & $0.119^{* *}$ & $-0.198^{* *}$ & $-0.220^{* *}$ & $-0.203^{* *}$ & $-0.232^{* *}$ & $-0.124^{* *}$ & $0.133^{* *}$ \\
\hline L. guyonianum & $0.350^{* *}$ & $-0.217^{* *}$ & $-0.175^{* *}$ & $-0.223^{* *}$ & $-0.155^{* *}$ & $-0.126^{* *}$ & $0.381^{* *}$ \\
\hline C. monacantha & $0.162^{* *}$ & $-0.087^{* *}$ & $-0.070^{*}$ & $-0.096^{* *}$ & $-0.080^{*}$ & -0.047 & $0.153^{* *}$ \\
\hline C. tinctoria & 0.043 & -0.038 & -0.025 & -0.034 & -0.028 & -0.024 & $0.072^{*}$ \\
\hline C. cretica & $0.126^{* *}$ & 0.029 & 0.025 & -0.021 & $0.125^{* *}$ & $-0.092^{* *}$ & $0.135^{* *}$ \\
\hline M. nudicaulis & $-0.066^{*}$ & $0.141^{* *}$ & -0.004 & 0.032 & $0.078^{*}$ & $-0.075^{*}$ & $-0.136^{* *}$ \\
\hline S. fructicosa & -0.039 & 0.000 & $0.243^{* *}$ & $-0.095^{* *}$ & -0.037 & $-0.160^{* *}$ & $0.154^{* *}$ \\
\hline T. nudatum & -0.021 & -0.042 & $0.172^{* *}$ & $-0.068^{*}$ & $-0.078^{*}$ & -0.037 & 0.056 \\
\hline A. glaucum & -0.019 & 0.019 & 0.049 & $-0.074^{*}$ & $-0.075^{*}$ & $-0.096^{* *}$ & 0.036 \\
\hline A. littoralis & $-0.223^{* *}$ & $0.195^{* *}$ & $0.203^{* *}$ & $0.176^{* *}$ & 0.020 & $-0.109^{* *}$ & $-0.380^{* *}$ \\
\hline C. dactylon & $-0.425^{* *}$ & -0.037 & $-0.249^{* *}$ & -0.032 & $-0.204^{* *}$ & $-0.075^{*}$ & $-0.208^{* *}$ \\
\hline S. maritimus & $-0.436^{* *}$ & $-0.229^{* *}$ & $-0.438^{* *}$ & $-0.151^{* *}$ & $-0.339^{* *}$ & 0.025 & $-0.144^{* *}$ \\
\hline
\end{tabular}

Note: ${ }^{*}$ and ${ }^{* *}$ mean significance at $P<0.05$ and $P<0.01$ levels, respectively.

\section{Conclusions}

The studied wetlands have very low plant species richness. This poor floristic richness is directly related to soil and climatic conditions of the region. In fact, the determination of the vegetation can help to identify the relationships between the distribution of biological types and environmental factors. Although the vegetation cover differed in the study area, the distribution of plants, especially on the edge of the water body, is generally formed a zonal pattern. The saline habitats includes various plant species with different degrees of salt tolerance. Consequently, the spatial distribution of vegetation in the saline wetlands is depended on the interaction of soil properties (EC, moisture, $\mathrm{CaSO}_{4}, \mathrm{~K}^{+}, \mathrm{Ca}^{2+}$ and $\mathrm{Cl}^{-}$) and climatic conditions. In general, further studies across geographic gradients referring salt marsh plant zonation and soil properties at a large scale are needed to optimize the use of plants as bio-indicators in saline habitats. This may help in introducing the salt-tolerant plant species as a fodder resource in saline habitats and regenerating the degraded saline wetlands. 


\section{Acknowledgements}

We would like to thank the Saharan Bio-resources Laboratory, Safeguarding and Valorization, Kasdi Merbah University of Ouargla, Algeria for providing support for this research. We are also grateful to Prof. Guilhem BOURRIÉ and Dr. Youcef HALIS for critically reviewing the manuscript.

\section{References}

Abd El-Ghani M M, Amer W M. 2003. Soil-vegetation relationships in a coastal desert plain of southern Sinai, Egypt. Journal of Arid Environments, 55(4): 607-628.

Aboura R, Benmansour D, Benabadji N. 2006. Comparison and phyto-ecology of Atriplex of Oran (Algeria). International Journal of Mediterranean Ecology, 32: 73-84.

AFNOR. 1999. Soil Quality. Paris: AFNOR, 10-16. (in French)

Alkhverdiev F D. 1988. Indicational significance of mosaicism of meadows with dominance the Shoregrass (Aeluropus littoralis) in the coastal portion of flatland Dagestan. Soviet Journal of Ecology, 19: 191-194.

Arce M I, Gómez R, Suárez M L, et al. 2013. Denitrification rates and controlling factors in two agriculturally influenced temporary Mediterranean saline streams. Hydrobiologia, 700(1): 169-185.

Aubert G. 1978. Methods of Soil Analysis. Marseille: CRDP, 65-100. (in French)

Ayoub A T, Malcolm C V. 1993. Halophytes for Livestock, Rehabilitation of Degraded Land and Sequestering Atmospheric Carbon. Nairobi: UNEP Environmental Management Guidelines, United Nations Environment Programme. Nairobi, Kenya, 54-68.

Barrett G. 2006. Vegetation communities on the shores of a salt lake in semi-arid Western Australia. Journal of Arid Environments, 67(1): 77-89.

Bertness M D, Ellison A M. 1987. Determinants of pattern in a New England salt marsh plant community. Ecology Monographs, 57(2): 129-147.

Bertness M D. 1991a. Interspecific interactions among high marsh perennials in a New England salt marsh. Ecology, 72(1): $125-137$.

Bertness M D. 1991b. Zonation of Spartina patens and Spartina alterniflora in New England salt marsh. Ecology, 72(1): $138-148$.

Bisson J. 2003. Myths and Realities of a Coveted Desert, the Sahara. Paris: L'Harmattan, 72-93. (in French)

Brown G. 2006. The Sabkha vegetation of the United Arab Emirates. In: Khan M A, Böer B, Kust G S, et al. Sabkha Ecosystems. Volume II: West and Central Asia. Netherlands: Springer, 37-51.

Carreño M F, Esteve M A, Martinez J, et al. 2008. Habitat changes in coastal wetlands associated to hydrological changes in the watershed. Estuarine, Coastal and Shelf Science, 77(3): 475-483.

Chehma A. 2006. Catalogue of Spontaneous Plants in the Northern of Algerian Sahara. Dar Elhouda Ain M'lila, Algeria, 1-140. (in French)

Chenchouni H. 2012. Flora diversity of a lake at the Algerian low-Sahara. Acta Botanica Malacitana, 37: 33-44. (in French)

Chigani H K, Khajeddin S J, Karimzadeh H R. 2010. Soil-vegetation relationships of three arid Land plant species and their use in rehabilitating degraded sites. Land Degradation \& Development, 23(1): 92-101.

Clarke L D, Hannon N J. 1967. The mangrove swamp and salt marsh communities of the Sydney District: I. Vegetation, soils and climate. Journal of Ecology, 55(3): 753-771.

Clarke L D, Hannon N J. 1970. The mangrove swamp and salt marsh communities of the Sydney District. III. Plant growth in relation to salinity and waterlogging. Journal of Ecology, 58(2): 351-369.

Cooper A. 1982. The effects of salinity and water logging on the growth and cation uptake of salt marsh plants. New Phytology, 90(2): 263-275.

Daget D, Poissonet J. 1991. Meadows and Pasture: Methods of Study. Montpellier: Institute of Botany, France, 285-324. (in French)

Darmody R G, Foss J E. 1979. Soil-landscape relationships of the Tidal Marshes of Maryland. Soil Science Society of America Journal, 43(3): 534-541.

Dubief J. 1953. Essay on Surface Hydrology in the Sahara. Algiers: Service Scientific Studies, 26-103.

Duchaufour P. 1977. Genesis and Classification of Soil. Paris: Masson and Cie, 355-462.

García N, Cuttelod A, Abdul Malak D. 2010. The Status and Distribution of Freshwater Biodiversity in Northern Africa. Gland, Switzerland, Cambridge, UK and Malaga, Spain: IUCN, 134-175.

Gardi R. 1973. The Saharan ( $3^{\text {rd }}$ ed.). Paris: Kümmerly and Fery, 49-51. (in French)

González-Alcaraz M N, Jiménez-Cárceles F J, Álvarez Y, et al. 2014. Gradients of soil salinity and moisture, and plant distribution, in a Mediterranean semiarid saline watershed: A model of soil-plant relationships for contributing to the management. Catena, 115: 150-158. 
Gounot M. 1969. Vegetation Studies: Survey Methods. Paris: Masson, 215-284. (in French)

Halis Y. 2007. Encyclopedia of plants for the region of Souf; Saharan plants of the great Eastern Erg. Algiers: El Oued, $142-195$. (in Arabic)

Halitim A. 1988. The Soils of Arid Regions of Algeria. Alger: University Office Publication, 123-156. (in French)

Halitim A, Bensaid R, Bensaad A, et al. 2003. Gypsiferous soil (genesis, characterization and function). Report APAPEZA Laboratory. Algeria: University of Batna. 1-25. (in French)

Hamdi-Aissa B, Valles V, Aventurier A, et al. 2004. Soils and brine geochemistry and mineralogy of hyper arid desert playa, Ouargla Basin, Algerian Sahara. Arid Land Research and Management, 18(2): 103-126.

Heker H, Tomàs Vives P. 1995. The Status of Wetland Inventories in the Mediterranean Region. Slimbridge: Medwet Publication/IWRB Publication, 38.

Hoveizeh H. 1997. Study of the vegetation cover and ecological characteristics in saline habitats of Hoor-e-Shadegan. Journal of Research and Construction, 34(1): 27-31.

Khadraoui A. 2005. Water and Soil in Algeria (Management and Environmental Impact). Algiers: EMPAC Constantine, 210-213. (in French)

Khadraoui A. 2007. Soils and Hydraulic of Algerian Oasis; Characterization, Constraints and Development. Algiers: Dar Houma Alger, 122-125. (in French)

Khan M A. 1990. The relationship of seed bank to vegetation in a saline desert community. In: Sen D N, Mohammad S. Proceedings International Seed Symposium. India: Jodhpur, 135-145.

Khaznadar M, Vogiatzakis I N, Griffiths G H. 2009. Land degradation and vegetation distribution in Chott El Beida wetland, Algeria. Journal of Arid Environments, 73(3): 369-377.

Kherraze M E, Lakhdari K, Kherfi Y, et al. 2010. Floristic Atlas of the Righ Oued Valley by Ecosystem. Biskra: Scientific and Technical Research Centre for Arid Areas, 25-58. (in French)

Koull N, Chehma A. 2015. Soil-vegetation relationships of saline wetlands in North East of Algerian Sahara. Arid Land Research and Management, 29(1): 72-84.

Le Houérou H N. 1992. The role of saltbushes (Atriplex spp.) in arid land rehabilitation in the Mediterranean Basin: A review. Agroforestry Systems, 18(2): 107-148.

Le Houérou H N. 2001. Biogeography of the arid steppe land north of the Sahara. Journal of Arid Environments, 48(2): 103-128.

Malcolm C V, Choukr-Allah R. 1995. Characteristics and methods for determining the drilling species for particular sites. In: The Halophytes and Agriculture. New York: Marcel Dekker Inc., 97-114.

Ozenda P. 1991. Flora of the Sahara (3 ${ }^{\text {rd }}$ ed.). Paris: CNRS, 212-410. (in French)

Pennings S C, Callaway R M. 1992. Salt marsh plant zonation: The relative importance of competition and physical factors. Ecology, 73(2): 681-690.

Poupon H. 1980. Structure and Dynamics of the Woody Layer of a Steppe in the North of Senegal. Paris: ORSTOM, $300-319$. (in French)

Quézel P, Santa C. 1962. New Flora of Algeria and the Southernmost Desert Areas. Flight 1 and 2. Paris: CNRS, 443-526. (in French)

Richards L A. 1954. Diagnosis and Improvement of Saline and Alkali Soils. Agriculture Handbook-No. 60. Washington: USDA; 160.

Rogel J Á, Alcaraz Ariza F, Ortiz Silla R. 2000. Soil salinity and moisture gradients and plant zonation in Mediterranean salt marshes of Southeast Spain. Wetlands, 20(2): 357-372.

Rogel J Á, Silla R O, Ariza F A. 2001. Edaphic characterization and soil ionic composition influencing plant zonation in a semiarid Mediterranean salt marsh. Geoderma, 99(1-2): 81-98.

Roshier D A, Robertson A I, Kingsford R T, et al. 2001. Continental-scale interactions with temporary resources may explain the paradox of large populations of desert waterbirds in Australia. Landscape Ecology, 16(6): 547-556.

Slimani N. 2008. Characterization of some properties to adapt in the mid Saharan of the major spontaneous perennials plants in the region of Ouargla. MSc Thesis. Ouargla, Algeria: University Kasdi Merbah.

Snow A A, Vince S W. 1984. Plant zonation in an Alaskan salt marsh: II. An experimental study of the role of edaphic conditions. Journal of Ecology, 72(2): 669-684.

Soltner D. 1989. The Bases of the Vegetable Production. Volume 1: Ground. Anger: CSTA, 186-192. (in French)

Tug G N, Ketenoglu O, Bilgin A. 2012. The relationships between plant zonation and edaphic factors in halophytic vegetation around Lake Tuz, Central Anatolia, Turkey. Rendiconti Lincei, 23(4): 355-363.

Ungar I A. 1998. Are biotic factors significant in influencing the distribution of halophytes in saline habitats? The Botanical Review, 64(2): 176-199.

Viellefon J. 1979. Analysis of Gypsiferous Soils. Pedology Series 17. Cahiers: ORSTOM, 195-201.

Youcef H, Lamine B M, Hocine B, et al. 2012. Diversity of halophyte desert vegetation of the different saline habitats in the valley of Oued Righ, Low Sahara Basin, Algeria. Research Journal of Environmental and Earth Sciences, 4(3): 308-315. 